\title{
Predictors for aki in a cardiac surgery population undergoing cardio-pulmonary bypass
}

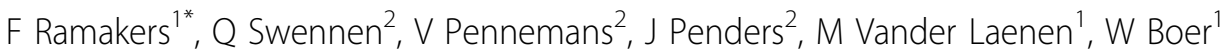 \\ From ESICM LIVES 2015 \\ Berlin, Germany. 3-7 October 2015
}

\section{Introduction}

In cardiac surgery involving cardio-pulmonary bypass, AKI is a relatively common diagnosis. In recent years a number of new biomarkers have been undergoing validation in this clinical setting. It is thought that earlier detection of AKI will offer opportunities for new therapeutic interventions

\section{Objectives}

Analysis of a database was performed to define baseline patient and biomarker characteristics in patients developing AKI in a population of cardiac surgery patients undergoing cardiopulmonary bypass as part of the procedure.

\section{Methods}

In total, 259 patients were enrolled, after the exclusion of patients with severe pre-existing renal insufficiency (defined as a eGFR $<15 \mathrm{ml} / \mathrm{min}$ ). As part of a broader study, urine and blood samples were obtained immediately before initiation of cardio-pulmonary bypass. Patients were subsequently retrospectively divided into 2 groups, AKI $(\mathrm{n}=84)$ and non-AKI $(\mathrm{n}=175)$. This subdivision was based on based on the AKIN criteria i.e. increase in s-Creat $\geq 0.3$ $\mathrm{mg} / \mathrm{dl}$ or $\geq 50 \%$ compared to baseline within $48 \mathrm{~h}$ or reduction in urine output $<0.5 \mathrm{ml} / \mathrm{kg} / \mathrm{h}$ for more than $6 \mathrm{~h}$. Statistical analysis of all characteristics before arrival on the ICU was performed.

\section{Results}

AKI patients $(32 \%$ of total) were older $(70 \mathrm{yrs}(\mathrm{SD}=9)$ vs 67 (11), p =0.043) with higher BMI's (27.7 (4.8) vs.26.7 (4.3), $\mathrm{p}=0.036)$. As to be expected baseline eGFR (CKD-EPI, in $\mathrm{ml} / \mathrm{min}$ ) was lower in the AKIgroup (69.49 (20.30) vs. $76.45(15.01), \mathrm{p}=0.024)$. Both baseline urinary-NGAL $(\mu \mathrm{g} / \mathrm{l})(1211$ (2172) vs.749 (946),

${ }^{1}$ Ziekenhuis Oost Limburg, Intensive Care and Anaesthesiology, Genk, Belgium

Full list of author information is available at the end of the article $\mathrm{p}=0.020)$ and serum-cystatin $\mathrm{C}$ (in $\mathrm{mg} / \mathrm{L})(0.98(0.39)$ vs $0.86(0.36), \mathrm{p}=0.0175)$ were statistically higher in the AKI group and CPB time (in minutes) was significantly longer: 163 (63) vs 121 (51), p < 0.0001 .

\section{Conclusions}

Urinary-NGAL and serum-Cystatin most likely reflect pre-existing kidney dysfunction (like eGFR). Length of cardiopulmonary bypass time is a significant factor for development of AKI, which is amenable to improvement.

\section{Authors' details}

'Ziekenhuis Oost Limburg, Intensive Care and Anaesthesiology, Genk, Belgium. ${ }^{2}$ Biomedical Research Institute, UHasselt, Diepenbeek, Belgium.

Published: 1 October 2015

\section{Reference}

1. Thiele RH, Isbell JM, Rosner MH: AKI Associated with Cardiac Surgery. Clin J Am Soc Nephrol 2015, 10(3):500-514, Mar 6.

\section{doi:10.1186/2197-425X-3-S1-A635}

Cite this article as: Ramakers et al:: Predictors for aki in a cardiac surgery population undergoing cardio-pulmonary bypass. Intensive Care Medicine Experimental 2015 3(Suppl 1):A635.

\section{Submit your manuscript to a SpringerOpen ${ }^{\odot}$} journal and benefit from:

- Convenient online submission

- Rigorous peer review

- Immediate publication on acceptance

- Open access: articles freely available online

- High visibility within the field

- Retaining the copyright to your article

Submit your next manuscript at $\boldsymbol{\nabla}$ springeropen.com

\section{SpringerOpen ${ }^{\odot}$}

C 2015 Ramakers et al.; This is an Open Access article distributed under the terms of the Creative Commons Attribution License (http:// creativecommons.org/licenses/by/4.0), which permits unrestricted use, distribution, and reproduction in any medium, provided the original work is properly cited. 